\title{
EFEK INDOOR AIR POLLUTION TERHADAP KESEHATAN
}

\author{
Wahyu Indah Dewi Aurora ${ }^{1}$ \\ ${ }^{1}$ Departemen IImu Kesehatan Masyarakat-Kedokteran Keluarga, \\ Fakultas Kedokteran Dan IImu Kesehatan Universitas Jambi \\ Email: auroradr@unja.ac.id
}

\begin{abstract}
In recent decades, indoor air quality has been of particular concern because of its contribution to health. It is estimated that as much as $90 \%$ of people spend their time indoors rather than outdoors. If the ventilation system is poor, it will result in an accumulation of pollutants in the room. These pollutants can come from outdoor air that enters the room, growing microorganisms, interior furniture or furniture or from the daily activities of humans themselves. The health problems that will be caused also vary. It can be from lung disease caused by inhalation of dangerous pollutants such as lung infections, pneumonia, asthma or COPD. Or other diseases such as Sick Building Syndrome, nasopharyngeal cancer, skin irritation, eye irritation, etc. To overcome this, careful planning is needed when building a room or building to minimize health problems due to indoor air, one of which is collaborating with several experts.
\end{abstract}

Keywords: Indoor Air Quality, Indoor Air Pollution, Health disease

\section{ABSTRAK}

Dalam beberapa decade terakhir,kualitas udara dalam ruangan menjadi perhatian khusus karena kontribusinya pada segi kesehatan. Diperkirakan ada sebanyak $90 \%$ orang-orang menghabiskan waktunya di dalam ruangan daripada di luar ruangan. Jika system ventilasi buruk, maka akan menghasilkan akumulasi polutan yang ada dalam ruangan. Polutan tersebut bisa berasal dari udara luar ruangan yang masuk ke dalam ruangan, mikroorganise yang tumbuh, perabotan atau furniture interior ruangan ataupun dari aktivitas keseharian manusia itu sendiri. Gangguan kesehatan yang akan diakibatkan pun bermacam-macam. Bisa dari penyakit paru akibat terhirup polutan yang berbahaya seperti penyakit infeksi paru, pneumonia, asma atau PPOK. Atau penyakit lain seperti Sick Building Syndrome, kanker nasofaring, iritasi kulit, iritasi pada mata, dll. Untuk mengatasinya perlulah perencanaan yang matang pada saat pembangunan sebuah ruangan atau gedung untuk meminimalisir gangguan kesehatan akibat udara dalam ruangan, salah satunya adalah berkolaborasi dengan beberapa ahli.

Keywords: Indoor Air Quality, Indoor Air Pollution, Health disease 


\section{PENDAHULUAN}

Diperkirakan bahwa orang-orang menghabiskan waktu sekitar $90 \%$ di dalam ruangan seperti rumah, sekolah, kantor, gedung olahraga, kendaraan, dll. Dengan demikian Indoor air quality memiliki dampak yang signifikan terhadap kesehatan dan kualitas hidup manusia. Bagi sebagian orang risiko kesehatan akibat terpapar polusi udara di dalam ruangan mungkin lebih besar dari yang ada di luar ruangan ${ }^{1}$. Ada penigkatan perhatian terhadap kualitas udara dalam ruangan dalam beberapa decade ini. Seperti diketahui bahwa desain bangunan terutama yang ada di kota-kota besar secara umum memiliki ciri: memanfaatkan lahan yang sempit dengan membangun secara vertical dan bangunannya dibuat dengan system ventilasi tersendiri yaitu dengan ventilation rate yang telah direduksi. Sehingga kualitas udara dalam ruangan pada bangunan tersebut pada umumnya akan tergantung pada system ventilasi yang digunakan dan sumber-sumber polutan mungkin ada dalam gedung tersebut ${ }^{2}$.

\section{TUJUAN}

Penelitian ini bertujuan untuk memberikan gambaran mengenai Indoor air pollution atau polusi udara dalam ruangan, serta efeknya terhadap masalah kesehatan. Hasil dari penelitian ini diharapkan dapat memberikan kontribusi pada masalah kualitas udara yang ada dalam ruangan serta kaitannya dengan masalah kesehatan.

\section{METODE}

Metode yang digunakan pada penelitian ini adalah Literatur review. Sumber datanya adalah artikel di dalam jurnal yang diunduh dari EBSCOhost, Science Direct, Google scholar dan Wiley Online Library, dengan penelitian mengenai Indoor air quality, Indoor Air Pollution dan masalah kesehatan yang ditimbulkan.

\section{HASIL DAN PEMBAHASAN}

\section{Kualitas Udara di Dalam Ruangan (Indoor Air Quality)}

Udara terdiri atas macam-macam gas dan nantinya akan membentuk lapisan atmosfer bumi. Udara murni kandungannya adalah $78 \%$ nitrogen, $21 \%$ oksigen, dan gas/ substansi lainnya hingga mencapai $100 \%$. Kandungan-kandungan tersebut bisa terdapat di udara secara alamiah (seperti kebakaran hutan, gunung meletus, mikroorganisme, dan zat kimiawi yang dihasilkan dari hewan atau tumbuhan). Ataupun juga dikarenakan aktivitas manusia (seperti emisi gas buang kendaraan bermotor, industri, termasuk aktivitas rumah tangga). Kandungan tersebut berupa senyawa/unsur kimia dan substansi biologis. Sebagiannya merupakan polutan yang sebenarnya tidak diharapkan ada di udara karena dapat mengganggu 
kesehatan manusia. Beberapa polutan yang terdapat di udara dan dihirup oleh manusia justru dihasilkan oleh aktivitas keseharian manusia. Kandungan yang sering ditemukan antara lain adalah Ozon (O3), Total Suspended Particulate (TSP), Particulate Matter dengan diameter < 2.5 (PM2.5) atau Particulate Matter dengan diameter < 10 (PM10), sulfur dioksida (SO2), karbon monoksida (CO), karbon dioksida (CO2), nitrogen oksida (NOx), dan senyawa organic yang mudah menguap (VOCs). Masing-masing kandungan itu dan beberapa substansi lainnya seperti logam beracun dan berbagai senyawa organik persisten dapat memiliki efek kesehatan terhadap manusia ${ }^{2}$.

\section{Polusi Udara di Dalam Ruangan (Indoor} Air Pollution)

Jika system ventilasi buruk, maka akan menghasilkan akumulasi polutan yang ada dalam ruangan. Polutan tersebut bisa berasal dari berbagai sumber, bisa dari udara luar ataupun dari peralatan dan akitivitas yang terdapat dalam ruangan itu sendiri. Sumber polutan dalam ruangan diantaranya bisa karena asap rokok, komponen yang ada dalam bangunan serta furniture dan emisi dari gas buang peralatan kantor $^{2,3}$.

Kualitas udara di dalam ruangan dapat dipengaruhi oleh polutan yang berasal dari berbagai sumber. Yang paling umum polutan tersebut bersumber dari 3 hal, yaitu sumber polutan dari luar yang masuk ke dalam ruangan, pembakaaran atau sumber memasak dari dalam ruangan dan sumber kimiawi ${ }^{3}$. Pertama, ada dua sumber pencemar utama yang berasal dari luar ruangan yang dapat masu ke dalam ruangan, yaitu ozon (O) dan material partikulat (PM). Polutan Ozon adalah bentuk fotokimia yang berasal dari sinar matahari dan nitrogen oksida(NOX3) dan juga senyawa orgaink yang mudah menguap (VOC). Yang dimaksud dengan polutan udara menurut adalah karbon monoksida, radon, asbes,formaldehid, hidrokarbons, dan beberapa bahan kimia organic lainnya, ozon, asap tembakau, beberapa microorganism, fiberglass, ammonia dan pestisida ${ }^{4}$.

\section{Sumber-Sumber Polutan Udara Dalam Ruangan}

Ada beberapa sumber potensial yang menyebabkan polusi pada udara ruangan. Sumber-sumber tersebut adalah ${ }^{4}$

1. Udara dari Luar ruangan. Kontminasi udara bisa berasal dari luar ruangan baik secara sengaja atau tidak sengaja. Udara tersebut masuk melalui ventilasi atau AC. Udara yang masuk dapat berupa tanah, emisi, gas dan kelembaban.

2. Sistem HVAC (Heating, ventilation or Air Conditioning). System HVAC ini 
dianggap sebagai agen penyebab pada Sick building syndrome. Karen sifatnya berada di lingkungan yang hangat dan lembab, maka mikroba seperti jamur dan bakteri dapat tumbuh dan berkembang. Mikroorganisme ini terbawa oleh debu dan kotoran dari system ventilasi dan dapat menyebarkan organic yang dapat menguap (VOC) seperti heksana, metil chlonaik, benzene dan aseton

3. Kontruksi bangunan atau renovasi. Konstruksi bangunan interio seperti perabotan yang baru, karpet, dinding atau renovasi di beberapa tempat dapat dapat menimbulkan masalah udara akibt debu dan serat yang berkontribusi terhadap kontaminasi udara dalam ruangan

4. Komponen bangunan. Seperti papan, kayu lapis, bahan insulasi, ubin langitlangit, em karpe, kain, gorden atau perabotan baru diketahui dapat memancarkan formaldehida ke lingkungan dalam ruangan

5. Air dari luar. Kerusakan interior udara dikarenakan adanya air yang tergenang di atas gedung atau sekitarnya juga dapat mempengaruhi kualitas udara dalam ruangan, di mana idesangat ideal untuk tumbuhnya mikroba

6. Sumber pemanas. Seperti kompor gas, kompor kayu, perapian, tungku dan pemanas ruangan berkontribusi terhadap pelepasan produk pembakaran seperti karbon monoksida, nitrogen oksida, dan lain-lain

7. Lainnya. Asap tembakau di dalam ruangan akan melepaskan ammonia, karbon dioksida dan formaldehid. Mesin fotokopi dan mesin listrik yang lain akan memancarkan ozon.

\section{Efek Indoor Air Pollution Terhadap Kesehatan}

Kualitas udara dalam ruangan yang tidak baik akan menyebabkan berkembangnya penyakit kronis seperti asma, sensitifitas, dan pneumonitis hipersensitif. Selain itu dapat juga menyebabkan kondisi yang bersifat sementara tetapi dengan gejala yang lebih luas seperti sakit kepala, mata kering, mual, kelelahan, hidung tersumbat, dan jika gejala-gejala tersebut muncul disebut dengan Sick building syndrome. Bagi orang yang telah memiliki kondisi medis tertentu seperti asma, gangguan jaringan ikat, alergi atau imunosupresi maka resiko yang akan terjadi lebih besar ${ }^{5}$.

Penelitian yang dilakukan oleh (Mu et al., 2013) terhadap wanita yag tidak merokok di Cina, menunjukkan bahwa adanya korelasi dari Partikulat Material di dalam ruangan akibat memasak, pemanasan dan ventilasi terhadap risiko terjadinnya kanker paru (lebih tinggi 3 kali dari kontrol), di mana setiap $10 \mu \mathrm{g} / \mathrm{m}$ 
peningkatan particular material dikaitkan dengan $45 \%$ peningkatan risiko kanker paru-paru 6 .

Efek buruk dari Polusi udara dalam ruangan yaitu menghasilkan 2 juta kematian premature per tahunya, di mana $44 \%$ karena pneumonia, 54\% dari penyakit paru obstruktif kronik (PPOK) dan $2 \%$ dari kanker paru-paru. Kelompok yang terkena dampak adalah perempuan dan anak-anak yang banyak menghabiskan waktu di dalam ruangan. Morbiditas terkait dengan polusi di dalam ruangan yaitu penyakit pernapasan seperti infeksi saluran pernapasan akut, COPD, BBLR, Kanker nasofaring,laring dan paru-paru, dan leukemia ${ }^{7}$. Efek kesehatan yang berbahaya akibat formladehid adalah menjadi iritan akut yang akan mengurangi kapasitas vital paru, menyebabkan bronchitis, menjadi karsinogen sehingga menyebabkan leukemia dan kanker paru ${ }^{8}$.

Partikulat material menyebabkan infeksi pernapasan, bronchitis kronis, PPOK, dan juga PPOK eksasebasi akut. Sulfur dioksida dan nitrogen dioksida menyebabkan mengi dan eksasebasi asma. Risiko perinatal juga buruk yaitu berat bayi lahir rendah dan kematian perinatal meningkat karena adanya paparan karbon monoksida. Biomassa asap, terutama ion logam dan aromatic polisiklik, dapat menimbulkan katarak. Polisiklik aromatic hidrokarbon dapat menyebabkan perkembangan kanker paru-paru, mulut, nasofaring dan laring ${ }^{7}$.

\section{Sick building syndrome}

Sick building syndrome adalah istilah dimana penghuni suatu ruangan mengalami gangguan kesehatan yang bersifat akut dan efek tersebut terkait dengan seberapa banyak ywaktu yang dihabiskan di dalam ruangan. Akan tetapi, tidak terdapat penyakit ataupun penyebab yang khas yang dapat diidentifikasi. Keluhan-keluhan tersebut dapat dilokalisasikan pada zona ataupun daerahdaerah tertentu ataupun mungkin tersebar di seluruh ruangan pada bangunan. Akan tetapi, ada istilah "Building Related IIInes (BRI)" dimana maksudnya adalah jika gejala penyakit tersebut didiagnosis dan sudah dapat dipastikan penyebabnya adalah kontaminan ruangan yang ada di udara ${ }^{9}$.

Konsep Sick building syndrome muncul pertama kali pada tahun 1982 yang dibuat oleh WHO dengan judul "Sick building syndrome". Pada tahun 1984 seorang epidemiologi Inggris membandingkan 9 gedung dengan system ventilasi yang berbeda-beda. Penelitian ini meneliti komponen-komponen yang menyebabkan Sick building syndrome yaitu mata, selaput lendir, lesu, kulit kering dan sakit kepala ${ }^{10}$. Gejala dan tanda yang muncul adalah biasanya sakit kepala, pusing, mual, iritasi mata atau tenggorokan, 
batuk kesulitan konstentrasi, kelelahan, gejala seperti flu, asma yang meningkat, alergi dingin, kepekaan terhadap bau, suara serak dan perubahan kepribadian. Penyebab timbulnya gejala itu sendiri tidak diketahui ${ }^{11}$. Menurut Buckler dalam Tsacoyianis 2008, gejala-gejala dan tanda dari SBS sering muncul dimana akibat dari kontaminasi karena Kualitas udara jauh dibawah standar udara dalam ruangan ${ }^{4}$.

Penyebab dari Sick building syndrome dikutip dari Enviromental Protection Agency adalah ${ }^{9}$ :

1. Ventilasi Yang Tidak Memadai

Ventilasi yang tidak memadai salah satunya dapat terjadi akibat seistem Heating, Ventilating and Air Conditioning (HVAC) tidak efektif mendistribusikan udara ke orang-orang yang ada dalam gedung. Padahal system ini menjadi factor penting dalam kejadian SBS.

2. Kontaminasi Kimiawi yang berasal dari dalam ruangan

Sebagian besar polusi udara dalam ruangan berasal dari sumber yang ada di dalam ruangan itu sendiri. Seperti perekat, pestisida, pelapis, karpet, produk kayu buatan, dan pembersih yang mengandung senyawa organic yang mudah menguap ( $V O C$ ) salah satunya formaldehid. VOC yang tertinggi disumbangkan oleh asap dari tembakau. Beberpa penelitian menunjukkan VOC dapat menyebabkan efek kesehatan secara akut dan kronis pada konsentrasi tinggi.

3. Kontaminasi kimiawi yang berasal dari luar ruangan

Polusi udara di dalam ruangan juga dapat berasal dari udara luar yang masuk ke dalam ruangan. Contohnya seperti polutan dari knalpot kendaraan, bangunan pembuangand dan pipa saluran air. Polutan tersebut dapat masuk akibat ventilasi udara yang buruk, jendala dan bangunan terbuka lainnya. Selain itu, produkpembakaran juga dapat masuk ke dalam gedung dari garasi terdekat.

4. Kontaminasi dari factor biologis

Contohnya adalah jamur, bakteri, virus, dan serbuk sari. Kontaminant tersebut dapat tumbuh dan berkembang di saluran air, ruangan lembab, atau di mana air tergenang di karpet, ubin, atau langit-langit. Gejala fisik akibat kontaminasi biologis seperti dada sesak, batuk, demam, nyeri otot, menggigil dan alergi, serta infeksi saluran pernapasan atas. Salah satu bakteri yang ada dalam ruangan, yaitu Legionella, telah menyebabkan penyakit Demam Pontiac dan Penyakit Legionnaire. 
REKOMENDASI

MASALAH

Setelah mengetahui akar

permasalahan dari polusi di dalam ruangan, maka pihak perancang bangunan haruslah bekerjasama dengan beberapa profesi lain, seperti ahli hygiene industry untuk memeriksa adanya kontaminasi udara, ahli mikrobiologi jika permasalahannya adalah jamur atau bakteri, insinyur yang memeriksa desain dan system ventilasi serta dokter yang berpegalaman dalam kedokteran okupasi dan lingkungan ${ }^{5}$.

\section{KESIMPULAN}

Jadi dapat ditarik kesimpulan bahwa Polusi Udara Dalam Ruangan (Indoor Air Pollution) adalah salah satu factor penyebab gangguan permasalahan kesehatan, mengingat hampir $90 \%$ orang banyak menghabiskan waktu di dalam ruangan. Jika kualitas udara dalam ruangan itu tidak baik, atau banyak terdapat polutanpolutan berbahaya, maka akan menyebabkan banyak sekali gangguan kesehatan, baik dalam waktu dekat atau akut, ataupun dalam waktu yang panjang atau kronik. Gangguan kesehatan yang ditimbulkan dapat berupa penyakit paruparu seperti infeksi pernapasan akut (pneumonia), asma, PPOK, PPOK eksaserbasi akut, kanker paru, kanker nasofaring, kanker laring. Penyakit lain yang dapat ditimbulkan seperti Sick Building syndrome, mata kering, iritasi kulit, berat badan bayi lahir rendah, dkk. Perlu usaha preventif untuk selanjutnya agar dapat meminimalisir terjadinya gangguan kesehatan akibat Indoor Air Pollution. Diantaranya yang dapat dilkukan adalah dengan berkolaborasi dengan berbagai pihak professional dalam perancangan gedung dan ruangan, serta dalam proses pemeliharaan gedung itu sendiri

\section{REFERENSI}

1. Cincinelli, A., \& Martellini, T. (2017). Indoor Air Quality and Health. Int J Environ Res Public Health, 14.

2. Camelia, A. (2011). Sick Building Syndrome dan Indoor Air Quality. Jurnal IImu Kesehatan Masyarakat

3. Lin, B., Huangfu, Y., Lima, N., Jobson, B., Kirk, M., O'Keeffe, P., . . . Cook, D. J. (2017). Analyzing the Relationship between Human Behavior and Indoor Air Quality. Journal of Sensor \& Actuator Networks, 6(3), 1-18. doi: 10.3390/jsan6030013

4. Tsacoyianis, R. (2008). Indoor Air Pollutants and Sick Building Syndrome: A Case Study and Implications for the Community Health Nurse. Public Health Nursing, 14(1), 58-75. doi: doi:10.1111/j.15251446.1997.tb00411

5. Oliver, L. C., \& Shackleton, B. W. (2010). The Indoor Air We Breathe. Public Health Reports, 113(5), 398 
6. Mu, L., Liu, L., Niu, R., Zhao, B., Shi, J., Li, Y., . . Zhang, Z.-F. (2013). Indoor air pollution and risk of lung cancer among Chinese female non-smokers. Cancer Causes \& Control, 24(3), 439-450. doi: 10.1007/s10552-012-0130-8

7. Kankaria, A., Nongkynrih, B., \& Kumar Gupta, S. (2014). Indoor Air Pollution in India: Implications on Health and its Control. Indian Journal of Community Medicine, 39(4), 203-207. doi: 10.4103/0970-0218.143019

8. Sapkota, A., Gajalakshmi, V., Jetly, D., Roychowdhury, S., Dikshi, R., Brennan, P., \& al, e. (2008). Indoor air pollution from solid fuels and risk of hypopharyngeal/laryngeal and lung cancers: A multicentric case control study from India. Int J Epidemiol, 37

9. EPA. (1991). Indoor Air Fact: Sick Building Syndrome. from Environmental Protection Agency

10. Jaakkola, J. J. K. (2008). The Office Environment Model: A Conceptual Analysis of the Sick Building Syndrome*. Indoor Air, 8(S4), 7-16. doi: doi:10.1111/j.1600-0668.1998.tb00002.

11. Joshi, S. M. (2008). The sick building syndrome. Indian Journal of Occupational \& Environmental Medicine, 12(2), 61-64 